\title{
PRACTICE
}

\section{Institutionalization and Sustainability of Undergraduate Research across Disciplines at a Public, Urban Community College: Successes and Challenges}

\author{
Joan Petersen, Maria Mercedes Franco, Sharon Lall-Ramnarine, \\ Queensborough Community College, City University of New York \\ Shiang-Kwei Wang, Harold Washington College, City Colleges of Chicago
}

\begin{abstract}
Undergraduate research (UR) is an integral part of the culture at Queensborough Community College, CUNY (QCC), an urban community college with a diverse student population. Since 2015, more than 400 students participate in undergraduate research experiences each year, working with more than 40 faculty mentors from several academic departments. Although a large proportion of this research occurs within STEM fields, the social sciences, nursing, business, arts, and the humanities are also represented and have increased research activity each year. This article describes the various approaches of QCC to institutionalize, promote, and support UR; approaches to handling the challenging aspects of sustaining UR at a community college; and recent initiatives to expand UR across disciplines.
\end{abstract}

Keywords: high-impact practices, institutionalization, partnerships, sustainability, undergraduate research

doi: 10.18833/spur/4/3/16

Community colleges face a number of unique challenges when establishing an undergraduate research program. Heavy teaching loads and other commitments leave faculty with limited time to pursue their research interests. Community colleges often lack adequate facilities and funding resources to support faculty research. In addition, many nontraditional students face their own barriers to seeking out research experiences: they often have significant work and family obligations, and may not perceive themselves as researchers. These challenges are particularly prevalent at public, urban institutions like Queensborough.

30 Scholarship and Practice of Undergraduate Research
Despite these difficulties, numerous reports show that engaging undergraduate students (including community college students) in research has a strong positive impact on STEM students (President's Council of Advisors on Science and Technology 2012; Brandt and Hayes 2011; Hensel and Cejda 2015) and non-STEM students (Stanford et al. 2017). Recognizing this connection, QCC has developed a well-structured and sustainable program that supports UR in its various modalities (shown in Figure 1).

Undergraduate research at Queensborough Community College (QCC-UR) was formally institutionalized in 2014, leading to a larger and more unified presence on campus. This successful expansion has been facilitated by a multifaceted approach that includes a robust administrative support system (at the college and university levels) and several campus programs and initiatives.

\section{About Queensborough}

Queensborough Community College (QCC) is part of the City University of New York (CUNY), the largest urban, public university system in the United States. It is located in the northeastern part of Queens - one of the most diverse counties of the nation. QCC's student body reflects the borough's diversity: students come from 130 countries, and 32 percent report speaking a language other than English at home. The college employs about 415 fulltime faculty within 17 academic departments. QCC offers 37 associate degree programs, five certificate programs, and for-credit/nondegree programs.

Equally committed to open-admission access and academic excellence, QCC thus supports student learning in innovative ways. For example, the college has institutionalized 
FIGURE 1. Research Opportunities Offered at OCC

\begin{tabular}{|c|c|}
\hline $\begin{array}{c}\text { Funded UR Programs } \\
\text { e.g. CUNYResearch Scholars } \\
\text { Program } \\
\sim 110 \text { students/year }\end{array}$ & $\begin{array}{c}\text { Internship/Research } \\
\text { Assistantships on/off campus } \\
\text { e.g. REUs, government } \\
\text { agencies/laboratories } \\
\sim 16 \text { students/year }\end{array}$ \\
\hline $\begin{array}{r}\text { UR OPPO } \\
\text { OFFERE }\end{array}$ & $\begin{array}{l}\text { TUNITIES } \\
\text { AT OCC }\end{array}$ \\
\hline $\begin{array}{l}\text { Research Courses/Independent } \\
\text { Studies/Honors Projects } \\
\text { Offered in } 12 \text { Departments } \\
\sim 80 \text { students/year }\end{array}$ & $\begin{array}{l}\text { Research in the Classroom } \\
\text { Offered in 7-11 Departments/year } \\
\quad \sim 400 \text { students/year }\end{array}$ \\
\hline
\end{tabular}

Note: $\mathrm{QCC}=$ Queensborough Community College, CUNY. UR = undergraduate research. REU = Research Experience for Undergraduates Students may participate in more than one opportunity (e.g., students can be supported by a UR program while taking a UR course).

6 of the 11 high-impact practices (HIPs) described by the American Association of Colleges and Universities (Kuh 2008). HIPs are teaching and learning practices proven beneficial to college students from all backgrounds: some reports suggest that students from historically underserved populations benefit the most (Brownell and Swaner 2009; Finley and McNair 2013; Huber 2010; Kuh 2008; NSSE 2007). Each QCC HIP has a faculty coordinator who works closely with the Center for Excellence in Teaching and Learning (CETL) to promote and support HIPs on campus. Pedagogical and financial support for the HIPs fall under the purview of CETL (CETL n.d.).

\section{The Development of the QCC-UR Program}

QCC has had a long-standing history of involving undergraduate students in research, primarily as the result of externally funded faculty-driven efforts. This commitment to UR resulted in numerous publications and presentations at national conferences, as well as multiple student awards.

Participation in CUR's NSF Community Colleges Initiative (Council on Undergraduate Research n.d.) in 2012 helped the Office of Academic Affairs assert its readiness for the institutionalization of UR. UR benefited from de facto inclusion in the college's strategic planning and leveraged the structure and resources already dedicated to support HIPs at the college (CETL office). Additionally, efforts by the CUNY Office of Research to promote and support UR at community colleges provided momentum for the development of QCC-UR.

A multidisciplinary Faculty Inquiry Group (FIG) was charged with jump-starting the research in the classroom modality, developing student learning outcomes, and designing and facilitating professional development training for new faculty practitioners. UR became an official HIP in spring 2014, and the chair of the FIG became the faculty coordinator for undergraduate research and the research integrity officer. Members of the FIG formed the "UR Team" that helped mentor faculty and assisted CETL and the UR coordinator in advancing the UR agenda on campus. In 2016-2018, the UR team was expanded into a Research Committee composed of faculty representatives from each academic department, the library, the Office of Grants/Sponsored Programs (OGSP), the Kupferberg Holocaust Center, and the UR-HIP faculty coordinator. The Research Committee meets monthly and provides a forum for faculty to receive updated information about research events and resources on campus, and to discuss each department's questions, concerns, and suggestions.

The Research in the Classroom (RIC) modality gained further momentum when QCC became a partner college of the Community College Undergraduate Research Initiative (CCURI) in 2016. This modality promotes equity and inclusion in UR, as it reaches a greater number of students than the apprenticeship model (Caplan and MacLachlan 2014) and is not restricted to select students (Hewlett 2018; Shanahan et al. 2017).

In 2018, the college created an Office of Research and established a dean for research position (unique for CUNY community colleges) to provide oversight of all research (including UR) on campus. The dean oversees the OGSP and the Research Committee, directs QCC's CUNY Research Scholars Program (CRSP), collaborates with CETL and the UR-HIP coordinator, acts as a liaison between faculty and administration, and maintains the Undergraduate Research and Office of Research webpages. These webpages highlight student and faculty success and share information about UR opportunities. The dean also ensures compliance with IRB regulations and research training for students and faculty.

The UR-HIP coordinator works closely with the dean for research and CETL to collect information about UR initiatives on campus via periodic surveys, offers UR-HIP training for new practitioners, and arranges gatherings ("checking in" sessions and brown-bag lunch discussions) where experienced UR practitioners share their best practices with others. A timeline of the events that led to the development of QCC's current UR infrastructure is shown in Figure 2; a diagram outlining that infrastructure is shown in Figure 3.

\section{Programs and Partnerships That Support QCC-UR}

QCC-UR is supported by several grants, programs, and partnerships that provide funding and other resources for both faculty and students. For example, the CUNY Research Scholars program (CRSP) was developed in 
FIGURE 2. Timeline for QCC-UR Institutionalization and Sustainability Efforts

\begin{tabular}{|c|c|}
\hline Year & Event \\
\hline 2012 & CUR Community Colleges Initiative Workshop held at QCC \\
\hline 2013 & $\begin{array}{l}\text { OAA announced plans to institutionalize UR: five-member Faculty Inquiry Group (FIG) } \\
\text { appointed to lead institutionalization efforts }\end{array}$ \\
\hline 2014 & $\begin{array}{l}\text { UR is institutionalized as a HIP: Professional development efforts and the research in } \\
\text { the classroom (RIC) modality are launched, FIG renamed UR Team } \\
\text { The CUNY Research Scholars Program (CRSP) is launched - Cohort 1: } 15 \text { QCC students }\end{array}$ \\
\hline 2015 & CRSP Cohort 2: 20 QCC students \\
\hline 2016 & $\begin{array}{l}\text { QCC participates in CUR's National UR Week celebration } \\
\text { CRSP Cohort 3: } 30 \text { QCC students } \\
\text { UR Team grows into college-wide UR Committee with reps from all departments } \\
\text { QCC becomes CCURI College Partner } \\
\text { QCC holds 1st Annual UR Day }\end{array}$ \\
\hline 2017 & $\begin{array}{l}\text { National UR Week Celebration } \\
\text { CRSP Cohort 4: } 32 \text { QCC students }\end{array}$ \\
\hline 2018 & $\begin{array}{l}\text { National UR Week Celebration } \\
\text { QCC establishes its Office of Research and Dean for Research position } \\
\text { CRSP Cohort 5: } 29 \text { QCC students } \\
\text { Purview of UR Committee expanded/committee renamed Research Committee }\end{array}$ \\
\hline 2019 & $\begin{array}{l}\text { National UR Week Celebration and QCC's 1st virtual UR Showcase } \\
\text { QCC's 1st Student Spring Symposium } \\
\text { CRSP Cohort 6: } 28 \text { QCC Students } \\
\text { QCC's UR Brown Bag Lunch Discussion Series is launched }\end{array}$ \\
\hline 2020 & $\begin{array}{l}\text { UR Brown Bag Lunch Discussion Series } \\
\text { CRSP Cohort 7: } 32 \text { QCC Students } \\
\text { 5th Annual UR Day (virtual) }\end{array}$ \\
\hline 2021 & $\begin{array}{l}\text { 2nd Student Spring Symposium and UR Brown Bag Lunch Discussions Series } \\
\text { scheduled (virtual) }\end{array}$ \\
\hline
\end{tabular}

FIGURE 3. UR Infrastructure at QCC

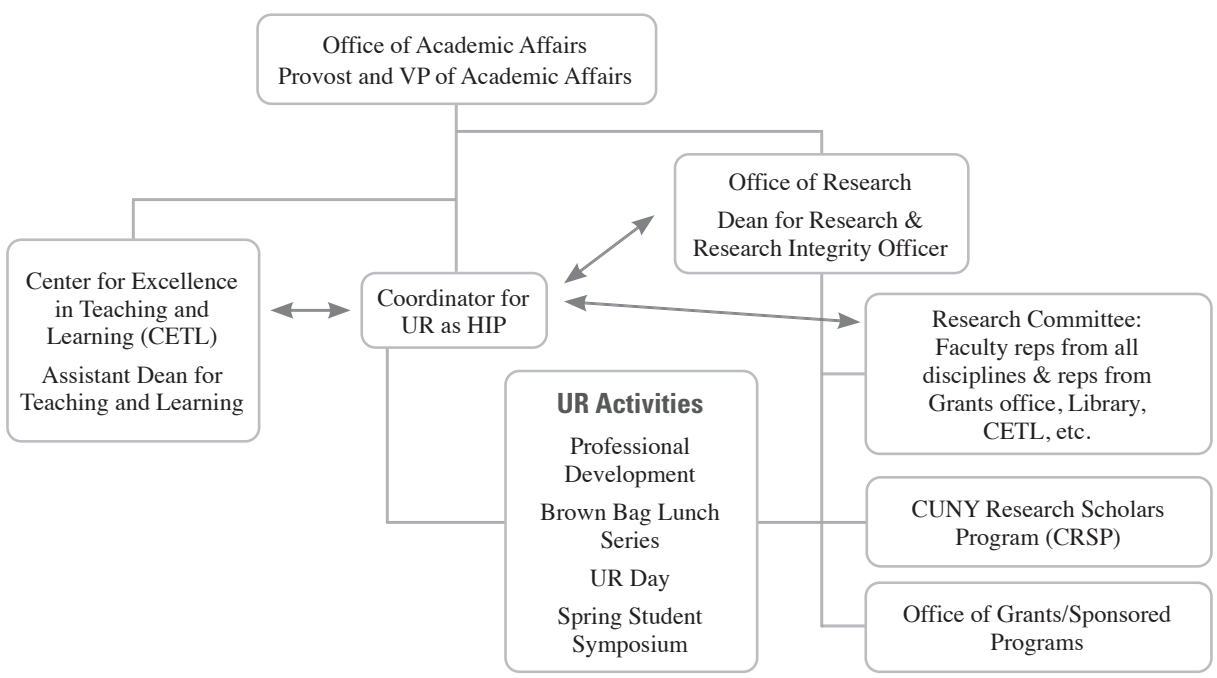

Note $: \mathrm{UR}=$ undergraduate research. $\mathrm{HIP}=$ high-impact practice 
2014 by the university to provide paid UR student-mentor opportunities in STEM and social sciences, as well as build a research community on campus. Each year, about 30 QCC students participate in CRSP and present at campus and CUNY-wide symposia (CRSP n.d.).

Several faculty members/teams have obtained external funding that directly supports student research (see Table 1A). The QCC NIH Bridges to the Baccalaureate program has been funding about 15 students per year since 2002 . In addition, faculty frequently obtain CUNY grants that support their research and may provide opportunities for students as well (see Table 1A). The OGSP works closely with faculty and the Office of Research to apply for and manage grants.

Many individual faculty members partner with outside organizations and maintain collaborations with other educational institutions to support and sustain their research. Table 1B shows examples of those partnerships and collaborations that have supported UR efforts, as well as government agencies that have hosted QCC student interns.

\section{Activities That Promote UR}

QCC has developed several special events and initiatives to support UR on campus, encourage interdisciplinary collaborations and student participation, and celebrate faculty and student UR accomplishments.

\section{Professional Development}

Professional development workshops (offered biannually), facilitated by the UR-HIP coordinator and CETL, help both novice and seasoned UR practitioners develop a research idea into a pedagogically sound, student- and learning-centered research experience for students. This approach differs from the more traditional, product-centered view of UR. UR-HIP practitioners may implement their projects as Independent Research courses, Honors projects, and/or Research in the Classroom experiences. Figure 4 shows the impact of UR-HIP trained mentors on student research exposure from 2014-2019.

\section{Undergraduate Research Day}

In 2016, a multidisciplinary group of QCC faculty representing biology (Joan Petersen), chemistry (Sharon LallRamnarine), mathematics and computer science (Maria Mercedes Franco), physics (Rex Taibu), and social sciences (Rommel Robertson) attended a CCURI Strategic Planning Workshop. The group decided to plan and implement the first Undergraduate Research Day-a campus-wide event that would bring together UR from all disciplines and in all modalities while celebrating the UR efforts of faculty and students. The first Undergraduate Research Day was held in December 2016 and included a luncheon, student poster session, and networking session. UR Day has become a highly successful annual event that occurs each fall and attracts more than 200 attendees. Participation in UR Day 2020 remained high despite the challenge of having to work remotely since March 2020. The number of UR faculty mentors who participate in UR Day each year remains steady at about 42-50 (Figure 5A). All six STEM departments at the college have been represented each year: participation by non-STEM departments has increased from 2 in 2016 to 5 in 2020 (see Figure 5B).

\section{Brown-Bag Lunch Discussion Series}

In fall 2019, QCC-UR launched an informal series of talks where faculty from various STEM and non-STEM disciplines speak about their UR projects and experiences (Office of Research n.d.) These talks provide a forum to encourage interdisciplinary collaborations and foster a greater understanding and appreciation of the various forms of UR across disciplines. Virtual brown-bag lunches in 2020-2021 included discussions of faculty adaptations of their UR projects to an online format.

\section{National UR Week}

Since spring 2016, QCC has celebrated national UR week by planning events in individual departments. In 2019, QCC hosted a virtual celebration that highlighted UR projects on the QCC website throughout the week (Office of Academic Affairs n.d.a). The event was shared with CUR to promote UR initiatives.

\section{Spring Student Symposium (SSS)}

In 2019, QCC-UR added a springtime campus-wide event that included oral presentations, musical performances, and readings to highlight all student accomplishments, including UR and other HIPs. Seventy-six UR students presented at this event. Although the campus closure forced cancellation of the 2020 event, it will be held virtually in 2021 during UR Week (Office of Academic Affairs n.d.b).

\section{QCC UR Journal}

This journal will publish results of student research from all disciplines. The inaugural issue, scheduled to be published in fall 2021, will include literature reviews and research plans of CSRP students who have been unable to do laboratory benchwork during the pandemic (Office of Academic Affairs n.d.c).

\section{The OCC-UR Student Experience}

Since QCC offers several modalities of UR across disciplines, students may have extensive research experiences before graduating. For example, a student who is exposed to UR in the classroom may then continue working one-on-one with a faculty mentor, enroll in sequential research courses, and/or serve as a summer intern. CRSP participants are supported for a full year of UR (including summer). QCC-UR events ensure that all participants have at least one or two chances to present their work. In addition to on-campus events and recognition, many 
TABLE 1. Select Funding Sources and Partnerships That Support UR

\begin{tabular}{|c|c|c|c|c|}
\hline A & & Program name & Funding source & Description (students served; year started) \\
\hline \multirow{13}{*}{ 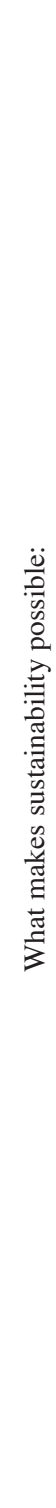 } & \multirow{8}{*}{ 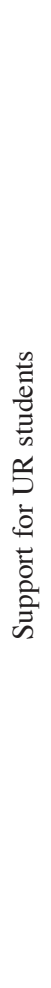 } & Bridges to the Baccalaureate & $\begin{array}{l}\text { National Institutes of } \\
\text { Health }\end{array}$ & $\begin{array}{l}\text { URE focused on underrepresentation and transfer to } \\
\text { baccalaureate programs in biomedicine or science } \\
\text { (15 per year; 2002) }\end{array}$ \\
\hline & & $\begin{array}{l}\text { Science Education Alliance-Phage } \\
\text { Hunters Advancing Genomics and } \\
\text { Evolutionary Science (SEA-PHAGES) }\end{array}$ & $\begin{array}{l}\text { Howard Hughes } \\
\text { Medical Institute } \\
\text { (HHMI) }\end{array}$ & $\begin{array}{l}\text { Research in the classroom (up to } 25 \text { students } \\
\text { per class; 2011) }\end{array}$ \\
\hline & & $\begin{array}{l}\text { Research Experiences for } \\
\text { Undergraduates (REU) }\end{array}$ & $\begin{array}{l}\text { National Science } \\
\text { Foundation (NSF) }\end{array}$ & $\begin{array}{l}\text { Research in physics, physics education, or interdisciplin- } \\
\text { ary projects in biology, the geosciences, or astronomy } \\
\text { (approximately } 9 \text { per year; 2014) }\end{array}$ \\
\hline & & $\begin{array}{l}\text { CUNY Research Scholars Program } \\
\text { (CRSP) }\end{array}$ & $\begin{array}{l}\text { City University of New } \\
\text { York (CUNY) }\end{array}$ & $\begin{array}{l}\text { Year-long, laboratory-based research experiences in } \\
\text { STEM and social sciences for associate degree students } \\
\text { (30 students in 2019-2020; since 2014) }\end{array}$ \\
\hline & & $\begin{array}{l}\text { CUNY-NASA Solar and Atmospheric } \\
\text { Research Program and Education } \\
\text { Partnership }\end{array}$ & $\begin{array}{l}\text { National Aeronautics } \\
\text { and Space } \\
\text { Administration (NASA) }\end{array}$ & $\begin{array}{l}\text { URE focused on underrepresentation in STEM } \\
\text { (4 students in 2018-2019; 2015) }\end{array}$ \\
\hline & & Smart Energy Scholars & $\mathrm{NSF}$ & $\begin{array}{l}\text { Scholarships for academically talented students who } \\
\text { demonstrate financial need, guaranteed transfer to } \\
\text { Binghamton University-SUNY (7 students in } \\
\text { 2018-2019; 2017) }\end{array}$ \\
\hline & & Summer Intensive Research Program & CUNY (since 2019) & $\begin{array}{l}\text { Trains social science students in research methods } \\
\text { (12 students in } 2019 ; 2017)\end{array}$ \\
\hline & & $\begin{array}{l}\text { The Harriet and Kenneth Kupferberg } \\
\text { Holocaust Center }\end{array}$ & $\begin{array}{l}\text { National Endowment } \\
\text { for the Humanities } \\
(\mathrm{NEH}) \text { and fund-raising }\end{array}$ & $\begin{array}{l}\text { Internship/fellowship project areas include archival } \\
\text { research, exhibition development, public programming, } \\
\text { and social media/marketing (approximately } 6 \text { students } \\
\text { per year) }\end{array}$ \\
\hline & & $\begin{array}{l}\text { Community College Research Grant } \\
\text { program }\end{array}$ & CUNY & $\begin{array}{l}\text { Track 1: Collaborative Research Incentive grants; } \\
\text { UR student participation highly encouraged. Track 2: } \\
\text { Mentored Undergraduate Research Grants (2016) }\end{array}$ \\
\hline & 离 & $\begin{array}{l}\text { Research in the Classroom Fellows } \\
\text { Program }\end{array}$ & CUNY & $\begin{array}{l}\text { Supports projects that integrate authentic research in the } \\
\text { curriculum (2016) }\end{array}$ \\
\hline & $\underset{\Xi}{\stackrel{\Xi}{\Xi}}$ & $\begin{array}{l}\text { William P. Kelly Research Fellowship } \\
\text { Program }\end{array}$ & CUNY & $\begin{array}{l}\text { Provides release time for tenured community college } \\
\text { faculty (2014) }\end{array}$ \\
\hline & 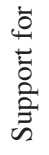 & PSC-CUNY Research Award Program & $\begin{array}{l}\text { CUNY and Professional } \\
\text { Staff Congress-CUNY }\end{array}$ & $\begin{array}{l}\text { Created and funded by the Collective Bargaining } \\
\text { Agreement between CUNY and the Professional Staff } \\
\text { Congress/CUNY, it supports the research and creative } \\
\text { works of full-time instructional staff }\end{array}$ \\
\hline & & $\begin{array}{l}\text { Pedagogical Research Challenge } \\
\text { Award }\end{array}$ & QCC & $\begin{array}{l}\text { Focused on research projects that impact student learning } \\
\text { outcomes }\end{array}$ \\
\hline
\end{tabular}

\begin{tabular}{|l|l|l|}
\hline \multicolumn{1}{|c|}{ Program name } & \multicolumn{1}{|c|}{\begin{tabular}{c} 
Description \\
\hline
\end{tabular}} & $\begin{array}{l}\text { Council on Undergraduate Research (CUR) } \\
\text { The Community Colleges Initiative is a catalyst for institutionalization efforts; } \\
\text { offer support for faculty/students presenting at CUR conferences. Showcases UR } \\
\text { activities on its national platform (e.g., Undergraduate Research Week) }\end{array}$ \\
\hline
\end{tabular}

Note $: \mathrm{UR}=$ undergraduate research. URE $=$ undergraduate research experience. $\mathrm{QCC}=$ Queensborough Community College, $\mathrm{CUNY}$

34 Scholarship and Practice of Undergraduate Research 
FIGURE 4. Impact of UR-HIP Trained Mentors on Student Research Exposure

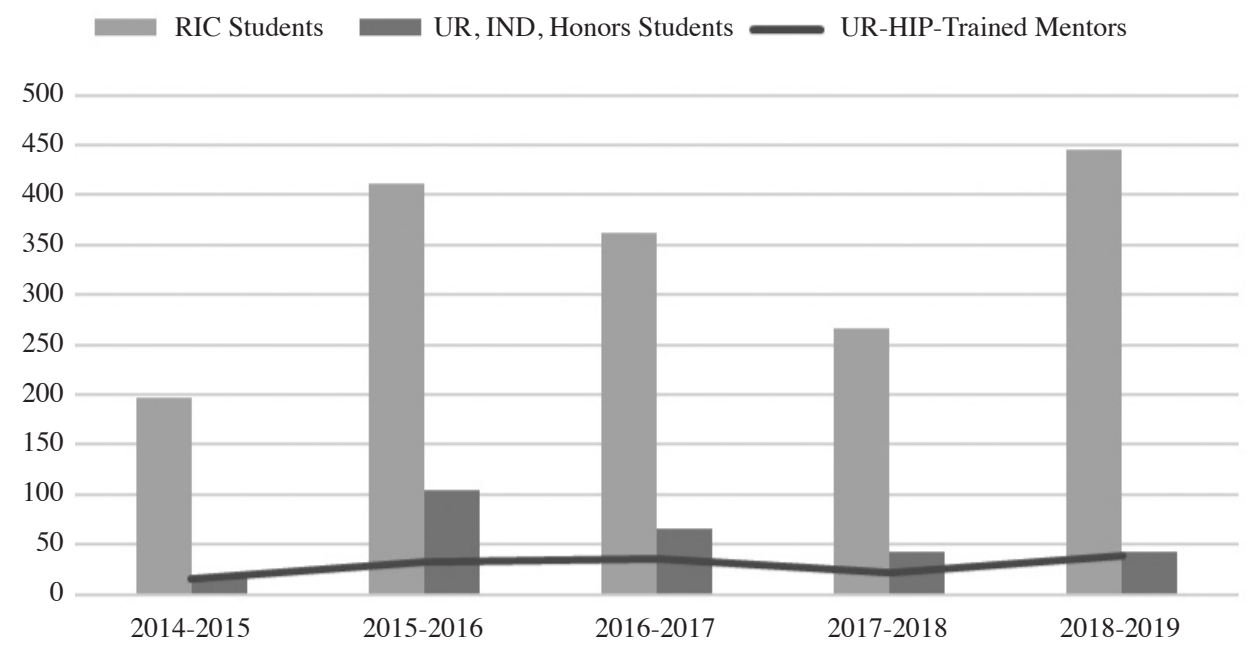

Note: Figure only reflects the number of students who have participated in undergraduate research (UR) with UR-HIP trained faculty either in Research in the Classroom (RIC) or Honors/Independent Research courses. HIP = high-impact practice

FIGURE 5. UR Day Participation, 2016-2020

A

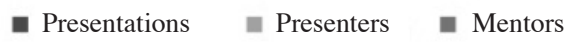

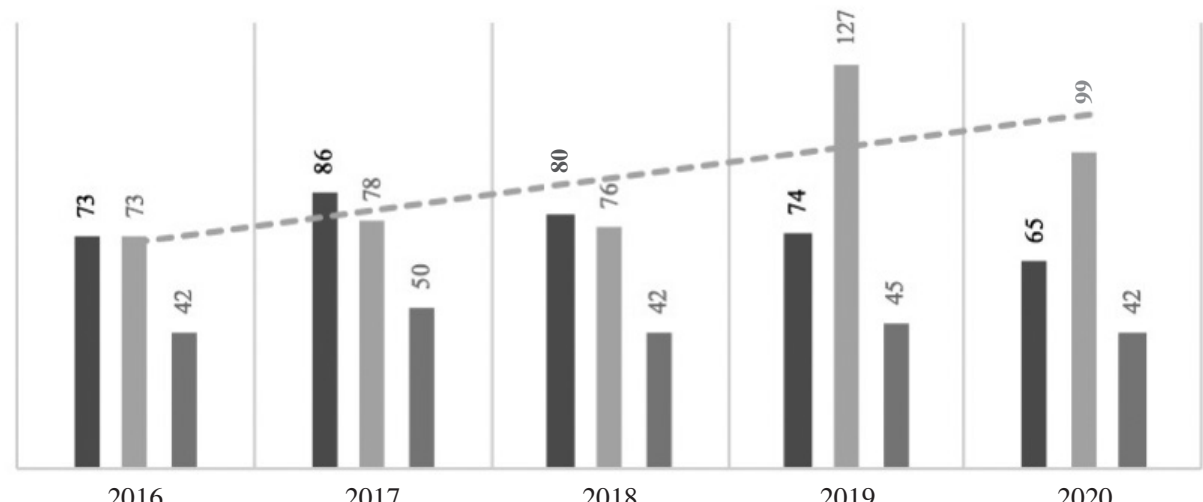

2016

2017

2018

2019

2020

B

- STEM = non-STEM

12

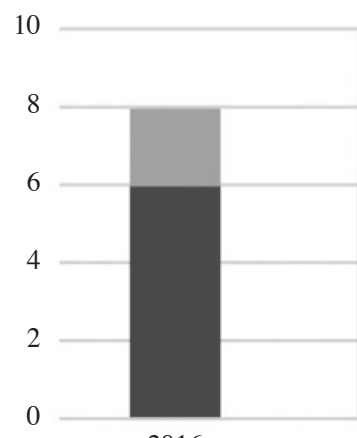

2016

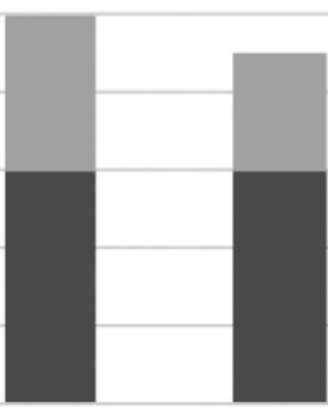

2018

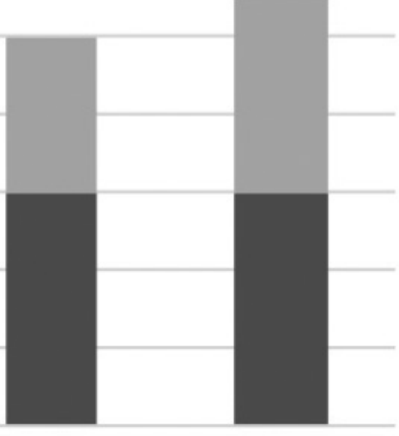

2019
2020

Note: Number of undergraduate research (UR) students and mentors (A), and number of departments (B), represented at UR Day. UR Day participants do not represent all QCC students who participate in research. 
students present and receive awards at regional, national, and international conferences. Travel may be funded by the research grant, the college, and/or by travel scholarships provided by the conference organizer.

QCC-UR students have received significant recognition for their achievements. Each year, QCC-UR students are accepted into Research Experiences for Undergraduates programs at highly regarded research universities (e.g., University of Pennsylvania, Vanderbilt University, and Columbia University) and participate in summer internships in industrial, national, and research laboratories (see Table 1). QCC students also have coauthored several peerreviewed publications.

As a result of these extensive UR experiences, QCC students are well-trained and highly competitive for opportunities beyond their QCC experience (Office of Academic Affairs n.d.d). Professional organizations, four-year colleges, and graduate programs have recognized the comprehensive UR preparation of QCC students and therefore recruit QCC students for educational and career opportunities.

\section{The OCC-UR Faculty Experience}

QCC-UR faculty also benefit from their mentoring experiences. UR practitioners recognize both the personal satisfaction and the positive impact on students, and most continue with this HIP after their first experience. Working with student researchers allows faculty to collect and analyze data that may be presented at conferences, published in peer-reviewed journals, and used to apply for additional funding. They may also publish and present the pedagogical aspects of their UR projects that may then be adopted by others. In faculty focus groups, CRSP mentors mentioned that having year-long support resulted in students who were both better trained and more committed to their research (Nerio et al. 2019). In addition, several UR mentors have been invited to participate in external UR initiatives, further enhancing their own professional development.

\section{The Measurement of UR Impact on Students}

Faculty surveys have provided information about the measurement of the impact of UR experiences on students. Individual UR practitioners assess learning outcomes in several ways, including evaluation of laboratory reports, laboratory notebooks, research papers, and presentations. They also use student surveys such as the Undergraduate Research Student Self-Assessment (URSSA), Classroom Undergraduate Research Experience survey (CURE), Survey of Undergraduate Research Experiences (SURE), and Student Assessment of Their Learning Gains (SALG) to track students' self-reported gains. All UR-HIP activities include student reflections. Currently, student assessments and reflections vary by discipline and by individual practitioners; one challenge that remains is developing a universal assessment of all UR experiences across disciplines and for all modalities of UR. Developing and implementing this assessment is planned for the 2021-2022 academic year.

The impact of CUNY's CRSP program, which supports approximately 240 STEM and social science projects per year throughout all CUNY community colleges, has been evaluated (Nerio et al. 2019); the results showed that participants were significantly more likely to graduate (59 vs. 50 percent) in almost all STEM fields. CRSP participants also demonstrated better retention in STEM and were more likely to transfer to research-active four-year institutions. Surveys of self-reported gains revealed that students felt more connected to their college; many attributed this to the efforts of their mentors.

\section{Success and Sustainability}

Four main components of the UR program have contributed the most to its success and sustainability:

1. Strong administrative support

2. Faculty buy-in

3. On-campus collaborations

4. External partnerships

Strong administrative support has clearly affected the ability to foster and grow the culture of UR on campus. This includes financial support for UR initiatives and faculty travel; logistical support for promoting UR on campus; and recognition and value placed on UR mentoring in the reappointment, tenure, and promotion process.

Faculty buy-in also has been an integral component of QCC-UR success. The college has adopted an inclusive view of what constitutes UR, recognizes that it can take many forms across disciplines, and encourages an interdisciplinary and transdisciplinary approach. Faculty are given opportunities to attend professional development sessions, check-ins, and other events that offer support throughout the planning and implementation of their UR projects. This has resulted in growth and continuity in UR: about 71 percent of the faculty members (58 out of 82) who have participated in UR-HIP professional development in the period 2014-2019 have continued to implement their UR course designs, affecting large numbers of students. In addition, new faculty continue to attend professional development for UR-HIP each year. To date, 87 faculty members from 12 departments have attended professional development workshops in UR-HIP (see Figure 6). In a spring 2021 UR survey, 23 percent of respondents (40 out of 174) indicated that they have published and/or presented with UR students, or about the impact of UR. In addition, 26 percent of respondents (45 out of 174) are currently implementing RIC or teaching independent research courses. This is consistent with five years of UR 
FIGURE 6. Participation in UR-HIP Professional Development Workshops

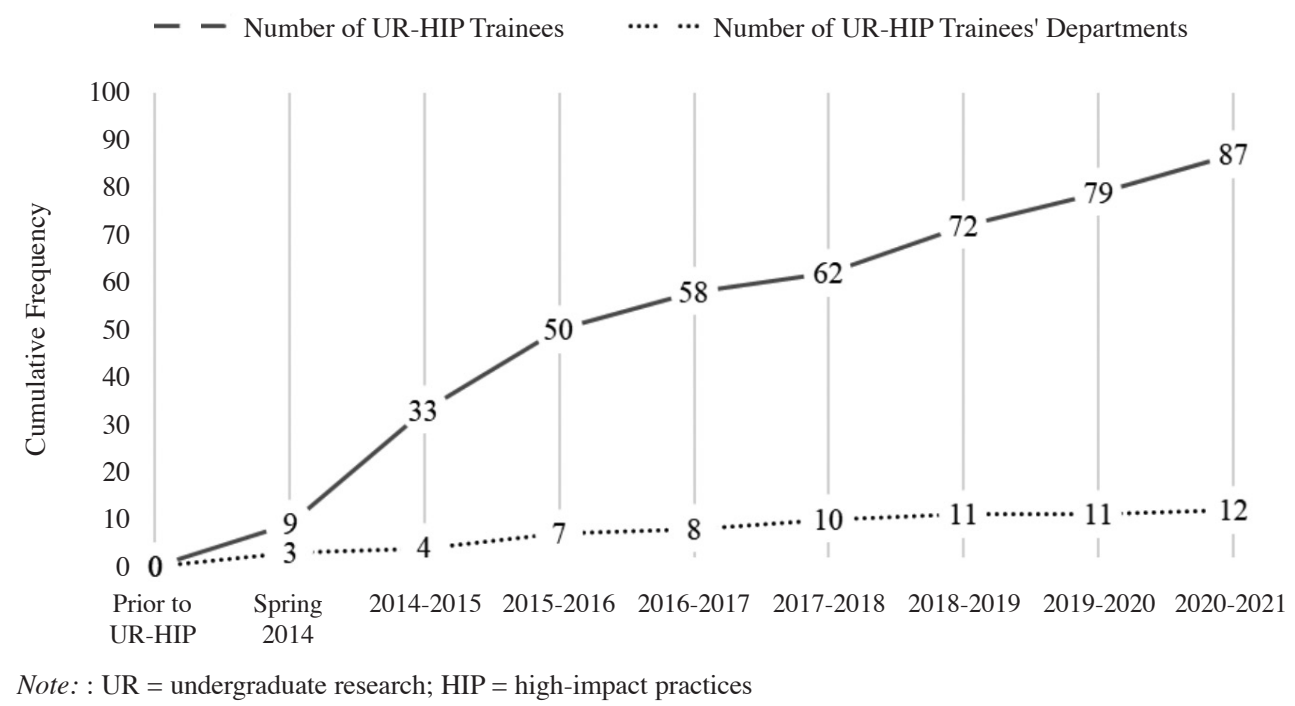

Day participation data indicating that, in a typical semester, 40-50 faculty engage in UR. It is remarkable that UR activity is being sustained at this level despite the college's closure and completely remote status for the past year due to the COVID-19 pandemic. The RIC modality has been particularly effective: an average of 400 students engage in RIC in a typical year (see Figure 4).

Another key to QCC-UR's success has been strong collaboration on campus that includes regular, effective communication among all faculty, staff, and administrators involved to discuss ideas, share information, and collectively support UR initiatives. In addition, several external partnerships - including collaborations with professional organizations, educational institutions, and government agencies that support UR - have resulted in countless opportunities for UR faculty and students that would not have been possible otherwise.

The success of QCC's UR model is also demonstrated by the growth of research courses in several departments. Between spring 2011 and fall 2013, the Department of Biological Sciences and Geology offered 1-2 sections per year of research courses (8-9 students): since institutionalization, the department has offered an average of 11-12 sections per year that enroll 39-40 students per year from spring 2014 to fall 2020. In the Mathematics and Computer Science Department, no research courses were offered before institutionalization - the department now offers 9-10 sections per year that enroll 12-13 students. Currently, UR courses are offered in 12 academic departments: Art and Design, Biological Sciences and Geology, Business, Chemistry, Engineering Technology, English, History, Mathematics and Computer Science, Nursing, Physics, Social Sciences, and Speech Communication and Theatre Arts.
The increased presence of UR on campus also is reflected in the amount of funding that directly supports UR students (see Figure 7). Grants that include direct support for UR students have increased about fivefold from 2013 to 2020 .

\section{Challenges and Goals}

On a recent faculty survey (spring 2019), the three most prevalent challenges identified by UR practitioners were time (41 percent of respondents, or 23 out of 56), lack of resources (20 percent of respondents, or 11 out of 56), and student readiness (12.5 percent of respondents, or 7 out of 56). Both faculty and students noted several other commitments that limit the time available to work on research. In particular, UR in the classroom practitioners mentioned facing challenges in balancing the research component with course content. Several faculty mentors also reported that the college does not have adequate facilities (lab space, supplies, and equipment) to support their research. Many faculty conduct their research at off-campus facilities, and difficulties with student travel, time schedule, and security access to these remote sites prevents the inclusion of QCC students. Student readiness was also mentioned as a challenge: students may lack the requisite skills needed to engage in research. This presents a unique challenge for course-based research when projects must be balanced with traditional course content, and limited time is available for research training.

Despite these challenges, faculty mentors persist in engaging students in UR, as they recognize the benefits to both students and to their own professional development (Laursen et al. 2010). QCC-UR has remained an integral part of the campus culture even during the pandemic as faculty have continued to engage students remotely. 
FIGURE 7. Growth in Funding for UR Programs on Campus

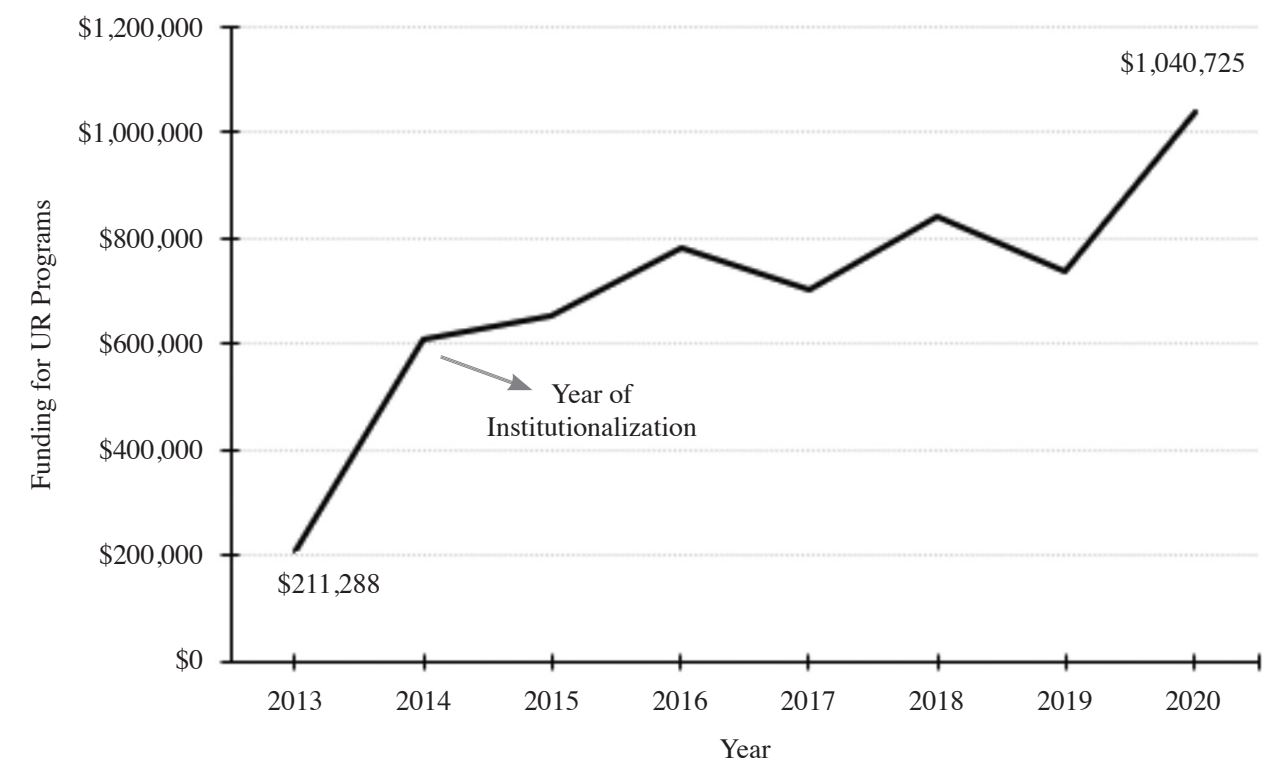

Note: : UR = undergraduate research. The figure reflects funding for programs that provide student stipends.

To address these challenges and increase the number of practitioners across all disciplines, the QCC-UR program seeks to expand the methods of support to faculty and students. Specific program goals include (1) developing a uniform assessment plan to measure the impact of UR and inform future initiatives; (2) promoting UR across all disciplines, with particular focus on the research in the classroom modality; and (3) increasing awareness of UR opportunities (conferences, funding resources, and publications) for both mentors and students, especially in non-STEM disciplines.

\section{Summary}

By institutionalizing UR as a HIP, QCC increased and diversified the opportunities for students to participate in meaningful research. The college has successfully grown UR to include authentic research embedded into the curriculum (resulting in an increase in the number of students reached) and created a student-centered and learningcentered approach to UR that stands across disciplines and research modalities. The UR infrastructure that has been built over the years provides students with a strong research background and a valuable skill set that will contribute to their success at a four-year institution and beyond. Recognition of QCC's successful UR program by institutional partners has led to collaborative research and professional development opportunities for faculty as well as scholarly and career opportunities for students. The QCC-UR program has been made sustainable by strong internal support as well as successful partnerships with outside organizations. The successful structure established by QCC can serve as a model for other institutions that seek to create or enhance UR programs on their campuses.

\section{References}

Brandt, LaRoy S. E., and Jack Lee Hayes. 2011. "Broader Impacts of Undergraduate Research at a Community College: Opening Doors to New Ideas." CUR Quarterly 33(1): 17-21.

Brownell, Jayne E., and Lynn E. Swaner. 2009. "High-Impact Practices: Applying the Learning Outcomes Literature to the Development of Successful Campus Programs." Peer Review 11(2): $26-30$

Caplan, Avrom J., and Effie S. MacLachlan. 2014. "An Overview of Undergraduate Research in the CUNY Community College System." In Tapping the Potential of All: Undergraduate Research at Community Colleges, edited by Brent D. Cejda and Nancy H. Hensel, 9-16. Washington, DC: Council on Undergraduate Research.

Center for Excellence in Teaching and Learning (CETL), Queensborough Community College-CUNY (QCC). n.d. "Home." Accessed April 26, 2021. https://www.qcc.cuny.edu/ CETL/index.html

Council on Undergraduate Research. n.d. "NSF Community Colleges Initiative." Accessed July 31, 2020. https://www.cur.org/ what/projects/past/tapping/

CUNY Research Scholars Program (CRSP), QCC. n.d. "Home." Accessed April 26, 2021. https://www.qcc.cuny.edu/ur/crsp.html

Finley, Ashley, and Tia McNair. 2013. "Assessing Underserved Students' Engagement in High-Impact Practices." Washington, DC: American Association of Colleges and Universities.

Hensel, Nancy H., and Brent D. Cejda. 2015. "Embedding Undergraduate Research in the Community College Curriculum." Peer Review 17(4): 27-30.

Hewlett, James A. 2018. "Broadening Participation in Undergraduate Research Experiences (UREs): The Expanding Role of 
the Community College." CBE-Life Sciences Education 17(3): es9. doi: 10.1187/cbe.17-11-0238

Huber, Bettina J. 2010. "Does Participation in Multiple High Impact Practices Affect Student Success at Cal State Northridge? Some Preliminary Insights." Office of Institutional Research, California State University, Northridge. Accessed July 30, 2020. https://www.csun.edu/sites/default/files/MultHIPOverviewFinal.pdf

Kuh, George W. 2008. High-Impact Educational Practices: What They Are, Who Has Access to Them, and Why They Matter. Washington, DC: American Association of Colleges and Universities.

Laursen, Sandra, Anne-Barrie Hunter, Elaine Seymour, Heather Thiry, and Ginger Melton. 2010. Undergraduate Research in the Sciences: Engaging Students in Real Science. San Francisco: Jossey-Bass.

National Survey of Student Engagement (NSSE). 2007. Experiences That Matter: Enhancing Student Learning and Success. Bloomington: Indiana University Center for Postsecondary Research.

Nerio, Ron, Althea Webber, Effie Maclachlan, David Lopatto, and Avrom J Caplan. 2019. "One-Year Research Experience for Associate's Degree Students Impacts Graduation, STEM Retention, and Transfer Patterns." CBE-Life Sciences Education 18(2): 1-9. doi: 10.1187/cbe.19-02-0042

Office of Academic Affairs, QCC. n.d.a "QCC's Celebration of National Undergraduate Research Week." Accessed April 26, 2021. https://www.qcc.cuny.edu/ur/URweek.html

Office of Academic Affairs, QCC. n.d.b "2021 Virtual Spring Student Symposium.” Accessed April 26, 2021. https://www.qcc. cuny.edu/ur/sss.html

Office of Academic Affairs, QCC. n.d.c "Queensborough Community College Undergraduate Research Journal." Accessed April 26, 2021. https://www.qcc.cuny.edu/urj/index.html

Office of Academic Affairs, QCC. n.d.d "Student Presentations at Conferences and Awards." Accessed April 26, 2021. https:// www.qcc.cuny.edu/ur/stu-present.html

Office of Research, QCC. n.d. "Professional Development \& Workshops.” Accessed April 26, 2021. https://www.qcc.cuny. edu/research/wwe.html

President's Council of Advisors on Science and Technology. 2012. Report to the President. Engage to Excel: Producing One Million Additional College Graduates with Degrees in Science, Technology, Engineering, and Mathematics. Washington, DC: Executive Office of the President.

Shanahan, Jenny Olin, Helen Walkington, Elizabeth Ackley, Eric E. Hall, and Kearsley A. Stewart. 2017. "Award-Winning Mentors See Democratization as the Future of Under- graduate Research.” CUR Quarterly 37(4): 3-8. doi: 10.18833/ curq/37/4/14

Stanford, Jennifer S., Suzanne E. Rocheleau, Kevin P.W. Smith, and Jaya Mohan. 2017. "Early Undergraduate Research Experiences Lead to Similar Learning Gains for STEM and Non-STEM Undergraduates." Studies in Higher Education 42(1): 115-129. doi: 10.1080/03075079.2015.1035248

\section{Joan Petersen \\ Queensborough Community College, \\ CUNY, JPetersen@qcc.cuny.edu}

Joan Petersen is a professor of biology, coordinator of the Environmental Science Program, and the UR-HIP coordinator at QCC. She has mentored many students via the apprenticeship model as well as in course-based research. In addition, she has worked extensively with local high school students and has engaged precollegiate students in course-based research. She is a currently a CUR Biology Division Councilor.

Maria Mercedes Franco is an associate professor of mathematics. In 2013-2014, she co-led institutional efforts that established UR-HIP and launched the research-inthe-classroom modality on campus. Between 2014-2016, Franco served as UR-HIP coordinator and founding campus director for the CUNY Research Scholars Program and was instrumental in securing QCC's participation in CCURI. She is co-principal investigator/co-director of MSRI-UP and CURM, two NSF-funded programs that support UR and address issues of underrepresentation in the mathematical sciences.

Sharon Lall-Ramnarine is a professor in chemistry, faculty fellow for research activities, and research integrity officer at QCC. In 2016-2018, she served as the UR-HIP coordinator and director of the CUNY Research Scholars Program. She was instrumental in creating the Research Committee and Office of Research on campus. She has mentored 35 UR students at QCC and Brookhaven National Laboratory, and coauthored 14 research papers with her mentees.

Shiang-Kwei Wang, vice president of academic and student affairs at Harold Washington College, City Colleges of Chicago, served as QCC's dean for research in 20182020. She was responsible for expanding and developing research activities and creative works on campus, ensuring compliance with federal legislation and CUNY policies, and for supporting QCC's research mission. Her research focuses on the impact of new media and technology on learning motivation and performance. 